\title{
RURAL AREAS AS THE ORIGIN AND DESTINATION OF PERMANENT INTERNAL MIGRATIONS BETWEEN 2002 AND 2017 IN POLAND. A LOCAL-LEVEL ANALYSIS (NUTS 5)
}

\author{
DARIUSZ ILNICKI \\ Department of Spatial Management, Institute of Geography and Spatial Management University of Wrocław, \\ Wrocław, Poland
}

Manuscript received: February 4, 2020

Revised version: May 11, 2020

ILNICKI D., 2020. Rural areas as the origin and destination of permanent internal migrations between 2002 and 2017 in Poland. A local-level analysis (Nuts 5). Quaestiones Geographicae 39(2), Bogucki Wydawnictwo Naukowe, Poznań, pp. 15-30. 4 figs.

AвstRAct: The main aim of the study is to identify the main streams of permanent migration and determine their reach. Special attention has been paid to rural areas (a rural commune, the rural area of an urban-rural commune) as the origin and destination of migration. The study has been conducted at the lowest level of territorial division in Poland (NUTS 5 - cities and communes). The analysed data cover the period between 2002 and 2017 and come from the online database Demografia GUS [Demography, Statistics Poland]. While presenting the volume and directions of migrations, the total and maximum values of migration have been considered. This approach allowed identifying the catchment areas as well as the areas of migratory attractiveness. These areas are highly similar in terms of their spatial extent. However, they differ significantly in terms of magnitude and reach of the main migration streams. Permanent internal migrations within rural areas are the least significant among all migration directions. One of their characteristics is the fact that they are short-distance migrations, occurring between neighbouring units. Permanent internal migrations appear to be a good indicator of urbanisation of suburban zones and the shaping of functional urban-rural-urban connections.

KEYWORDS: internal migration, rural areas, suburbanisation, origins and destinations of migration, the highest flow

Corresponding author: Dariusz Inicki, Faculty of Earth Sciences and Environmental Management, University of Wroctaw, ul. Kuźnicza 49/55, 50-138 Wroctaw, Poland; e-mail: dariusz.ilnicki@uwr.edu.pl

\section{Introduction}

Migration as a phenomenon is internally diverse (Arango 2000). This heterogeneity results from the diversity of the following aspects: motifs/reasons for migration, their spatial extent, and their permanence. In addition, migrations are not the subject of scientific disputes within a single field of knowledge. When analysing the phenomenon of migration, we can easily identify its numerous aspects: sociological, legal, economic, social and spatial - geographic (Brettell, Hollifield 2008; Casteles, Miller 2011). Moreover, the hierarchy of issues and problems connected with identifying the phenomenon of migration varies over time. The variability of problems can be defined as 'contemporary migratory movements'. However, they are contemporary at a particular point in time and do not always concern the same issue in the shorter or longer perspective. Clearly, 
it is difficult to present a complete catalogue of issues connected with migratory movements. Moreover, it is not possible for all the problems included in the catalogue to be separable. Putting aside, for a while, theoretical foundations of the phenomenon of migration, these problems can be divided into the following groups:

- investigating relationships between migratory movements and the demographic situation, socio-economic development and the labour market (e.g. Bałach-Frankiewicz et al. 2016; De Haas 2009; Faggian et al. 2007; Glick Schiller 2011; Hefner, Rauziński 2003; Przygalińska 2006; Rosner 2014);

- defining the character and specificity of migratory movements (e.g. Domańska 2006; Huk 2004; Massey et al. 1988; Tracz 2006);

- identifying the profit and loss account resulting from population movements (e.g. Böheim, Taylor 2007; Chapman, Bernstein 2003; Greta, Lewandowski 2007);

- creating and implementation of the migratory policy and the issues connected with the attitude towards migrants and their integration (e.g. Halik 2006; Iglicka 2006; Samoraj 2008; Teitelbaum 2008; Weinar 2006);

- legal regulations concerning migration and foreigners (e.g. Douglas et al. 2006; Hollifield 2008; Nita 2005; Schuck 2008; Wach 2007; Wójcik 2007);

- the study of the migration impact on family, especially that of economic migrations (e.g. Bramley et al. 2006; Massey 1990; Morrison et al. 2008; Pasamonik 2008; Slany 2008).

The above-mentioned issues are largely considered in the form of spatial analyses ${ }^{1}$. However, a permanent feature of the phenomenon of migration is its spatial dimension. The analyses incorporating the spatial dimension of migration are carried out mostly in the field of geography (e.g. Dennett, Stillwell 2008; Gober-Meyers 1978; Hardwick 2008; Molloy et al. 2011; Stillwell, Hussain 2010). Both in Poland, as well as worldwide, the research into migration has a long tradition and extensive source literature. Apart from spectacular international migrations, permanent internal migrations are important for the

It is disputable whether sheer mentioning a country's name can be regarded as a spatial analysis, or only when the phenomenon is depicted on a map. economy of the country or region. They generate both positive, as well as negative economic, spatial, as well as political and cultural effects. The study of permanent internal migration encompasses a whole range of analytical approaches. However, due to the limited access to data, the studies focusing on the spatial extent of internal migrations have been conducted relatively rarely. In this context, it's worth mentioning that the spatial scale of these studies was also diversified, as well as the problem of migration they discussed. Thus, there seems to be a local dimension to generalisations and conclusions concerning migration. This is derived mainly from the lack of access to this type of data in the public statistics ${ }^{2}$. Migratory data that takes into consideration the direction of movements were primarily accessible from two sources, that is, the PESEL register and/or the National Census of Population 1988. Thus, the phenomena were undertaken occasionally, but not sensu largo and concerned the actual movements between particular units of administrative or territorial division, or within the urban organism, accounting for the size and direction of movements. One might hypothesise that internal migrations following the post-war exodus of population from rural areas into the cities ceased to be the subject of research interest. They gave way to shuttle migrations, but since the second half of the 1990s, they have been regaining significance. At the moment, Polish public statistics have created a chance to fill this gap in inter- and intraregional studies of population migration.

Apart from the observations of a phenomenon, it is important to examine and explain its causes, determinants and its inherent mechanisms. These issues are the guiding principles of migration models. Migration models evolve. This evolution is the result of criticism directed at the existing models as well as incorporating the current, contemporary phenomena, mechanisms and processes. However, it is hardly disputable that migration rests on the foundations of laws by Ernst G. Ravenstein $(1885,1888)$, as well as neoclassical theory of Everette Lee (1966), the push-pull theory (Gregory 2009). Lee, in his theory,

As regards availability and accuracy of Polish public statistics, still at each lower level of territorial division the studies are becoming less and less detailed. In other words, it imposes a classical approach to presenting research problems. 
built on the concept of intervening opportunities proposed by Stouffer (1940). Based on his own observations, he formulated 19 hypotheses divided into 3 groups, which covered: (1) migration volume (2) streams and counter-streams, (3) migration (migrants') characteristics. Invoking both theories in the paper results from the fact that in the analytical part, the reader will find references to laws formulated by Ravenstein and Lee. Naturally, validation of the presented laws and hypotheses depends largely on the choice of data selected for the study.

\section{Research objective and scope. Data sources and research approach}

The data on permanent internal migrations, which take into account migration directions, have been publicly inaccessible until recently. They cover a relatively long period (2002-2017) and have not been comprehensively researched to date. The data in question concern the whole of Poland and are available at the lowest level of territorial division (NUTS 5 - cities and communes). The main objective of the present research study is to identify the main streams of permanent migration and define their spatial reach. Special attention shall be paid to rural areas. Migration will be analysed in the context of the following three pairs of relations: cities - rural areas, rural areas - cities; the flows between rural areas. The first pair of relations will allow identifying catchment areas that are made up of rural areas - rural areas as the source of migration to cities. The second pair of relations in which rural areas are destinations of permanent outmigrations from cities will help identify areas of migration attractiveness. The terms used in both cases - a migratory catchment area as well as migratory attractiveness ought to be treated as introducing newly coined terms. These terms are general as the reasons that lead to migration are unknown. The term catchment area is used to denote cities that are destinations of migration. The areas of migratory attractiveness are formed by cities that are the origin of migration. Thus, the absolute or relative number of migrations into a particular destination describes its attractiveness for migrants in a broad sense. Although the absolute number of migrations is determined by the size of the unit, which is the destination and/or the origin of migration, it may also be interpreted as the probability of the migration occurrence. At the same time, the unit size, measured by the population volume, determines the extent of migratory catchment areas and the areas of migratory attractiveness. In this context, a question arises concerning mutual relationships between spatial extent of these two types of areas as well as the flow magnitude. An accompanying objective of the study is the identification of interpretative and conclusion value of internal migrations taking into account migration directions as well as the inflow and outflow locations. The final issue is understanding the phenomenon of flows whose origins and destinations are rural areas. In this case, it will consist, among other things, in determining the degree of the diversity between particular regions - voivodeships (provinces) and the scale of these movements. It is important to note that the matrix of flows includes the volume of flows, which occur according to the rule 'each with each'. The implications are as follows:

- regardless of the scale of the analysis of flows, as well as a spatial reference unit, it is impossible to present all the movements;

- it is impossible to show return movements from unit $i$ to unit $j$, and from unit $j$ to unit $i$ for each case;

- it is impossible to analyse migration for all types of units of the administrative division at the NUTS 5 level.

Therefore, the following activities need to be undertaken: stratification of the analysis, incorporation of the uniqueness of the origin and destination of migrations as well as the greatest flows of migration from (origin) and to (destination).

The study of migration, migratory movements, as in the case of the study of commuting to the workplace, bases on the classical approach, that is, the presentation of the migration areas in the context of absolute or relative values from the point of view of the origin (inflow) or destination (outflow), and consequently, the balance of migration/commuting (Gawryszewski 1974, 1989; Herma 1962; Jelonek 2005; Kosiński 1968; Radwańska 2009; Rakowska 2014). The data on migration movements in a broad sense presented in a traditional approach can be obtained from The Local Data Base [Bank Danych Lokalnych]. Apart from this database, Statistics 
Poland [GUS] runs 11 other data bases, including 'Demography'. Among its outcome tables, one can find: (1) current research outcomes, (2) population forecast, (3) life expectancy, (4) population of gminas (hereinafter called communes) as of 31 December 2011 (NSP 2011). Among the above-mentioned categories, only the first one 'current research outcomes' contains such a set of data that allows studying the problem of migration from an untypical point of view. To be more exact, the part of Table $2 \mathrm{~g}$ that concerns (internal) migrations of the population, in particular, permanent internal migrations by communes of the previous and current address. It contains the magnitude of migratory flow between communes presented in the matrix system ${ }^{3}$. This system, although simple, unambiguous and clear, is completely useless for displaying the magnitude and directions of migration in a graphical manner. The matrix system of data requires data restructuring in a way that transforms into the initial state matrix $m \times n$ where $m-n$ into matrix $m^{2} \times 3$ whose three columns contain the following information: the commune of the current address (1), the commune of the previous address (2) and the magnitude of the flows between them (3).

Another nuisance connected with the afore-mentioned data is keeping the statistical secrecy in the understanding of the act on public statistics. It means that the box covered by statistical secrecy is filled with hash (\#). A question arises as to what, if anything at all, should be done about such a box? The answer could be 'nothing', as these movements have individual character, but do not concern particular persons. On the other hand, by ignoring them in the analysis, we 'get rid of' approximately 80 thousand movements per year'. In total, they account for $19 \%$ movements on average ${ }^{5}$. And when we fill 'the empty boxes' (\#) with minimum flows (one person) underestimation of movements falls to the average level, only slightly exceeding the

At the moment of submitting the manuscript for publication, the data was for the years 2002-2017.

4 The number of these not included movements is between slightly over 75 to nearly 89 thousand. Above, the average values are characteristic of 2006, 2007, 2010, 2011, 2012, 2013 and 2014.

5 In the case of underestimation in the period between $2002-2007$, it is on average nearly $18 \%$, and since 2008 , it is bigger by $1.5 \%$. total number of movements (4\%). In view of the above, it is not only advisable, but absolutely necessary to 'complete the data box' despite their underestimation ${ }^{6}$.

In the classical approach to analysing the phenomenon of migration, without spatial representation of migration directions, the quantities describing their scale are migratory inflow and outflow coefficients, and consequently, the migration balance coefficient. However, in the case of incorporating flows directions, it may be displayed with absolute volume of this flow. Such representation of the flow, though spectacular, as had been suggested before, favours large units. The value of both the absolute outflow and inflow magnitudes is a function of the unit's size. In the case of mutual relationships between the volume of inflow and outflow, however, it is possible that the outflow from a smaller unit to a larger one is bigger than the inflow from the larger unit into a smaller one. This regularity is more pronounced in the cases of urban - urban movements compared to the remaining three directions. The flow magnitude may be relativised by the population volume of the outward location or inward location.

A major problem in the dynamic studies, which take into consideration the spatial diversity, is identification of the stability, or territorial variability of the phenomenon, the structure of its spatial diversity. This issue becomes complicated together with an increase in the number of time points for which the study is carried out. In the case of the present study, an aggregate approach has been adopted. It means that in the general description of a phenomenon for a given analysis period, the author applies the sum

\footnotetext{
The lack of 'data completion' not so much precludes a comprehensive, global analysis of data, drawing conclusions and regularities as increases the margin of error, uncertainty regarding their correctness and strength. Data completion is crucial when presenting a phenomenon spatially at the local level - of particular units - (cities and/or communes), as on the one hand they constitute the background, the context for the occurring movements and on the other, display the extent of inflow/outflow areas. Clearly, by expanding the spatial scope, the number of spatial units, or examining a selected homogeneous group of units (e.g. cities, county cities, voivodeship capitals) smallscale movements are filtered out as they are only the background, the 'informational noise' for the mainstream of movements.
} 
of absolute/relative values for particular years, their mean, median and so on. The aggregate approach is legitimate in this case and it is validated by the following:

- applying principal components analysis separately for the inflow coefficient, outflow coefficients and the migration balance for all years jointly, each time we get one component, which is described by an indicator for each year ${ }^{7}$. The component of migration outflow is comparatively the weakest as regards the values of factor loadings and the common variation;

- virtually ideal correlation ${ }^{8}$ of the migration flow components with their mean values and their median.

Therefore, in the view of the above, it might be stated that the migratory movement was characterised by stability of spatial structures of its components (inflow and outflow) and the migration balance. In other words, values, their scopes might vary. However, the representation of spatial diversity does not change. Thus, the aggregate approach can be deemed possible and grounded.

\section{Rural areas as the origin of migration to cities - migration catchment areas}

Over the entire research period, nearly $1.5 \mathrm{~m}$ people migrated permanently to cities. In particular years, the number of migrants ranged between 86 and 112 thousand. Three periods can be distinguished in the variability of the movement number in relation to their absolute number. The first one covers the first four years, when the number of migrations fluctuated at around 93 thousand people. For the next two years, the number was close to 110 thousand annually. The third period, from 2008 to 2017, displayed a slight increase in the migration trends from 85 to 95

The values of factor loadings in all cases are greater by 0.730 . Only in the case of outflow component, the year 2002 is more weakly correlated with migratory outflow component $(0.684)$. It is worth noting that factor loading values are as high as the common variation, which for the inflow component, outflow component and migration balance are $83.4 ; 58.6 ; 76.6 \%$ respectively.

8 In all nine interrelations, the Pearson coefficient value is at least 0.986 . thousand. As regards the share of the significance of rural - urban migration compared to the total number of migrations between 2002-2017, it was $23.3 \%$. When analysing the significance of this direction of migration in particular years, after the first nine years of its rises and falls ${ }^{9}$, its nearly linear increase from 22 to $25 \%$ was observed.

As mentioned in the introduction to this paper, the highest total flow between units of a particular direction of flows has been used to identify migration catchment areas. In the case of rural - urban flows from the entire set of movements from a given rural commune, or rural area into a city, only the maximum rural - urban movement among $n$ movement was selected. In other words, we concentrate on a single movement to a given city. Cities are destinations only for maximum movements (Fig. 1). Therefore, they display the most important migration directions.

Maximum values constitute $47 \%$ of the total number of movements between cities and rural areas. As can be seen, such presentation of migrations depicts a clear division of space without overlapping of migration catchment areas of particular cities. This implies high degree of spatial coherence. There are, however, some exceptions to this general rule. They have one thing in common - they are voivodeship capitals. This particularly concerns the following cities: Warsaw, Cracow, Białystok, Łódź, Lublin, and to a lesser degree also Szczecin, Wrocław, Gdańsk and Kielce. The lack of spatial coherence, though to a lesser degree, can be observed in the cases of former voivodeships' capitals in the previous administrative system (e.g. Zamość).

Both the migratory catchment areas, as well as areas of migratory attractiveness might be assessed in terms of their scope/spatial expanse, clarity and significance. All these three characteristics only at first glance seem unrelated. When analysing spatial expanse, we could say it is largely a function of the city size. Apparently, it is modified by the density and geometry of the urban network. Spatial scope of migration catchment areas of cities divides Poland into an eastern and western part with larger and smaller catchment areas respectively (Rosner 2014). The division axis is determined by the line running from Tri-City to the Katowice Urban Area.

Fall from 24 to $22 \%$. 


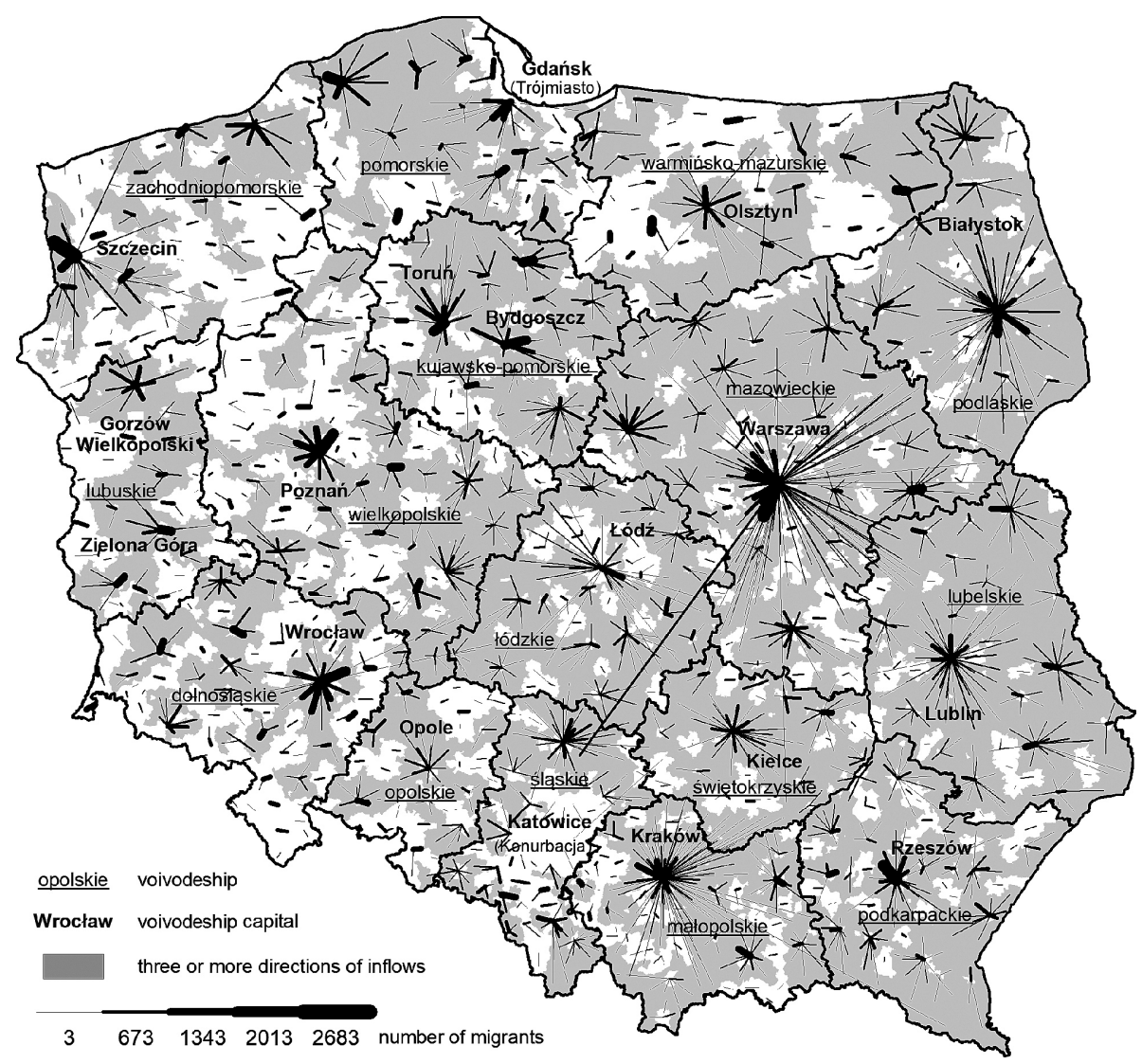

Fig. 1. Migratory catchment areas - rural areas as migration origins (linear scaling).

Source: elaborated on the basis of Statistics Poland - Demography database Table $2 \mathrm{~g}$ (http:/ / demografia.stat.gov.pl/ bazademografia/Tables.aspx).

If we take a closer look at the size of the catchment areas, we can find similarity to the partition line. If, however, the partition line is disputable, not clear enough, then the eastern part is bound to include the following voivodeships: Podlaskie, Mazowieckie, Łódzkie, Świętokrzyskie, Małopolskie, Podkarpackie and Lubelskie. The diversity of the spatial scope is observed not only for big cities (e.g. Wrocław, Poznań versus Białystok, Lublin and even Kielce) but also for smaller ones (e.g., Lubin, Głogów versus Ostrowiec Świętokrzyski, Stalowa Wola). Clarity of catchment areas understood as the number of rural areas attracted by cities (communes) also seems to divide the country into two above-mentioned parts. It is worth noting that not all migration catchment areas of cities are 'fully developed'. ${ }^{10}$ These underdeveloped catchment areas can be described as migration streams where the city interacts with its closest surrounding. There are many more

10 A fully developed migratory catchment area is the one into which migrants flow from three communes. underdeveloped catchment areas in the western part, compared to the eastern one. Clarity is indisputably the function of network density of cities, which may be, in some cases, modified by the share of forests in the total area. In the case of the significance of a catchment area, measured by the volume of movements, excluding the seats of voivodeships of the eastern part, the western part is privileged.

Finally, it is worth drawing attention to the issue which, not only throws a new light onto the study of migratory catchment areas and areas of migratory attractiveness, but also seems highly significant. Although migratory movements take place between all cities and rural areas in both directions, it is not the case for all cities when using the greatest flow and uniqueness of the origin and destination of migration. In the case of migratory catchment areas, nearly $28 \%$ of cities are not connected by the highest flow with any rural areas. The common feature of these cities is their location in the vicinity of the largest metropolitan centres. The distance separating them from 
these centres is not greater than 30-40 kilometres in a straight line. Thus, their impact zone is comparable to commuting distance, shuttle migrations, or the scope of functional areas (Dennett, Stillwell 2008; Gawryszewski 1974; Heffner, Gibas 2015; Ilnicki, Michalski 2015). Among the cities that have migratory catchment areas, as much as $66 \%$ are not developed. From among the remaining $34 \%, 21 \%$ constitute migratory catchment areas made up of three to five communes. Catchment areas with more than 10 communes constitute nearly $6 \%$. The biggest, most complex are catchment areas of Warsaw (93 communes) and Cracow (82). The following ones, with half smaller migratory catchment areas, are Białystok (46) and Lublin (42).

\section{Rural areas as the destination of outmigration}

As in the case of migration catchment areas, not each city has a migration-attractive area for its inhabitants. In this case, the share of cities that do not 'generate' migration into rural areas is bigger by $3 \%(31 \%)$. It should be stressed that this direction of migration is dominant in the total number of migrations for virtually the entire study period $^{11}$. This led to the total permanent outmigration of 2.1 million people between 2002 and 2017. In particular years, the number of migrants ranged between 110 and 160 thousand. The average annual value of migration reached 128 thousand and was the consequence of a clearly higher scale of migration in 2005 and 2006 (about 150 thousand each). From the global perspective, the volume of urban - rural movements fluctuated around 120 thousand. However, in the case of the share of the significance of urban - rural migration, in the total number of movements between 2002 and 2017, they accounted for nearly 32\%.

11 The first three of four years of the analysis constitute an exception when movements between cities were characterised by an average of $1.5 \%$ advantage (2002 $3.4 \% ; 2003-0.9 \% ; 2005-0.2 \%)$

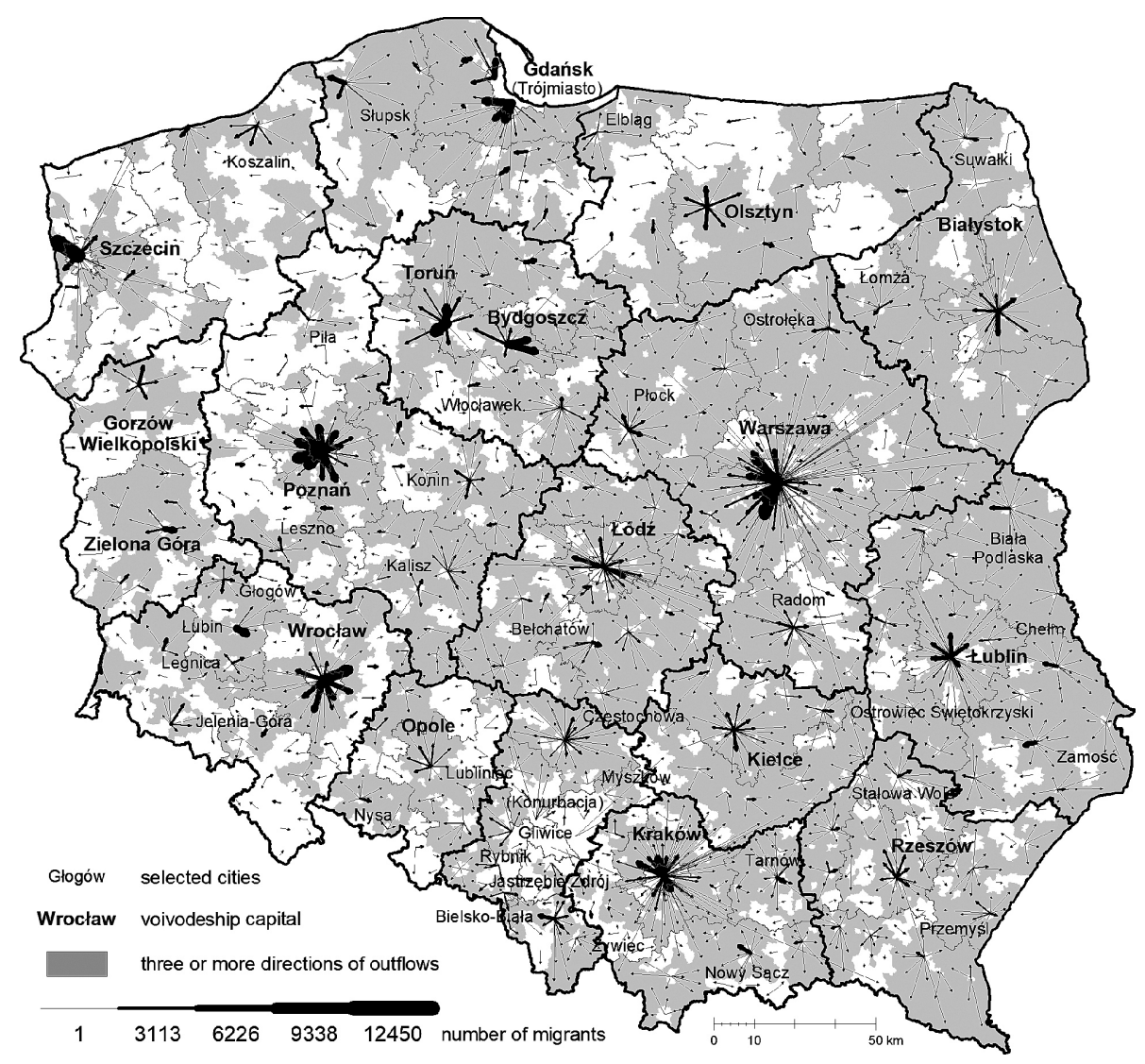

Fig. 2. Areas of migratory attractiveness - rural areas as outmigration destinations (linear scaling). Source: elaborated on the basis of Statistics Poland - Demography database Table $2 \mathrm{~g}$ (http://demografia.stat.gov.pl/ bazademografia/Tables.aspx). 
When splitting this migration direction into particular years, in the first six years, a clear upward tendency from 28 to $32 \%$ was observed, followed by a seven-year period of stability of the share at the level of about $32 \%$. The last four years displayed a fall and stabilised this direction at the level of $31 \%$.

Maximum flows cover nearly $61 \%$ of all urban - rural movements. It is worth noting that in absolute values, the highest, aggregate urban - rural flow is nearly twice as big (1.8) as the comparable flow in the opposite direction. The presentation of migration, with the use of the maximum flow, as in the previous case, displays a clear-cut division of space without visible at first sight overlapping of areas of migratory attractiveness (Fig. 2). Considerable similarity between the pictures, reach of the catchment areas and areas of migratory attractiveness are rather striking (Figs 1 and 2). One could argue that the degree of their spatial coherence is clearly higher than that of the catchment areas.

The observation concerning higher spatial coherence seems to be confirmed by the largest cities nationwide. These are, again: Warsaw, Cracow, Białystok, Łódź, Lublin, as well as Szczecin, Wrocław, Gdańsk, though to a lesser degree..$^{12}$ Examining the remaining cities, it can be seen that the areas of migratory attractiveness more often, compared to catchment areas, display a radial-shaped model of an impact zone. In addition, their expanse in each direction is highly similar, which makes for their regular shape. It should also be pointed out that spatial extent of migratory attractive areas, as well as migratory catchment areas, is determined by the city size. Likewise, it is modified by the density and geometry of the city network. Spatial extent of the city impact zone in a similar way to migratory catchment areas seem to divide Poland into eastern and western parts, with respectively bigger and smaller areas of migratory impact on their surroundings. It is worth noting that the country division line (Trójmiasto - Konurbacja Górnośląska [Tri-City - the Katowice urban area] is no longer as clear as in the previous case. At this point, one needs to mention the cities belonging to the Katowice urban area. These cities

12 In the case of Gdańsk, the area of migratory attractiveness is clearer, compared to its catchment area. hardly participate in the flows, where rural areas are the origin and/or destinations of migration. This results from the specific, different character of Śląskie Voivodeship as a whole among other voivodeships, and within it, its central part differing from the rest of the voivodeship. In Sląskie Voivodeship between 2002 and 2017, more than half of permanent migration $(52.7 \%)$ took place between cities. Urban - rural migrations, however, were the lowest of all the voivodeships, and their share in migratory flows was $22.9 \%$. As a result, Śląskie Voivodeship is divided into the three following parts:

- the northern one, covering the majority of former Częstochowskie Voivodeship, with a distinct area of migratory attractiveness and migratory catchment areas of Częstochowa, Lubliniec and Myszków;

- the central one, within the territory of former Katowickie Voivodeship with a distinctly shaped areas of migratory attractiveness in its western and southern part (Gliwice, Racibórz, Rybnik, Jastrzębie-Zdrój, Tychy);

- the southern one, with the impact zone of Bielsko-Biała and Żywiec.

Up until now, apart from visible but insignificant for the country and the analysis differences between spatial scopes of catchment areas and areas of migratory attractiveness for particular cities, they can be considered the same. Moreover, when comparing their pictures (Figs 1 and 2), it might be stated that catchment areas, compared to migratory attractive areas, are characterised by greater intensity, and therefore, are more identifiable nationwide and there are more of them. ${ }^{13}$ These statements are true, however, solely under the condition that they are interpreted in the light of the highest flow and presented in relation to the entire phenomenon - separately for both directions of movement. One might say that urban - rural movements constitute only, or as much as $137 \%$ of movements in the opposite direction. However, these 553 thousand migrants on the national scale is rather significant. The fact of over half a million more migrants moving from cities into rural areas is additionally intensified by selectivity of this migration direction manifested in

13 In this case, it concerns a visual presentation of these cities and their catchment areas, which are created by high movement values. 
the preference of large cities as origins of migration (Fig. 3).

If we were to identify areas with high 'intensity' of urban - rural migration, without (re)scaling, it would appear that there are merely around 10 large cities whose citizens settle the city's surrounding areas on a large scale (Fig. 2). A whole new picture and interpretative opportunities emerge if we disregard the highest values within the first two thresholds of migratory attractiveness. It can be stated that despite limitations of the statistics on migration resulting from statistical secrecy as well as frequent lack of updating address changes in the registry, two indisputable conclusions can be formulated. Firstly, the migration values are definitely high, and are generated by the current voivodeship cities, but also cities with poviat (district) status; in the latter case, it concerns in particular the former voivodeship capitals. At the same time, the scale of movements diminishes with decreasing significance of cities in the settlement hierarchy. Additionally, one or two directions are preferred in the case of smaller units. Apart from voivodeship capitals of the eastern part, individual values of movements are greater in the western part, despite its smaller spatial scope. Secondly, it must be acknowledged that the majority of movements take place within the distance of 30 kilometres in a straight line from the 'city centre'. The reach of the main movement streams overlaps with significant intensity of private construction as well as investment construction in the suburban zones (Ciok, Ilnicki 2018; Harańczyk 2015; Rettinger, Wójtowicz 2009). It should be borne in mind that outmigration concerns the generation of 30 and 40 year-olds, which means they mostly do not cut themselves off the city they migrated from (Dennett, Stillwell 2008; Kajdanek 2009; Łodyga 2011; Mantay 2009; Molloy 2011; Więcław-Michniewska 2006). Thus, they become participants of shuttle migrations, and consequently, create centrifugal and centripetal functional connections. Thereby, it might be concluded that incorporation of migration direction in the analysis allows identifying urban functional areas [MOF]. This does not mean that the information on the size and direction of migration is, or must be, the single quantity used for identification of urban functional areas. It seems that the aforementioned volumes of housing construction, together with the volume and directions of commuting would perfectly complement public statistics. However, in view of the methodology of their elaboration (unless they are available from the National Census of Population), they should be treated solely as auxiliary data.
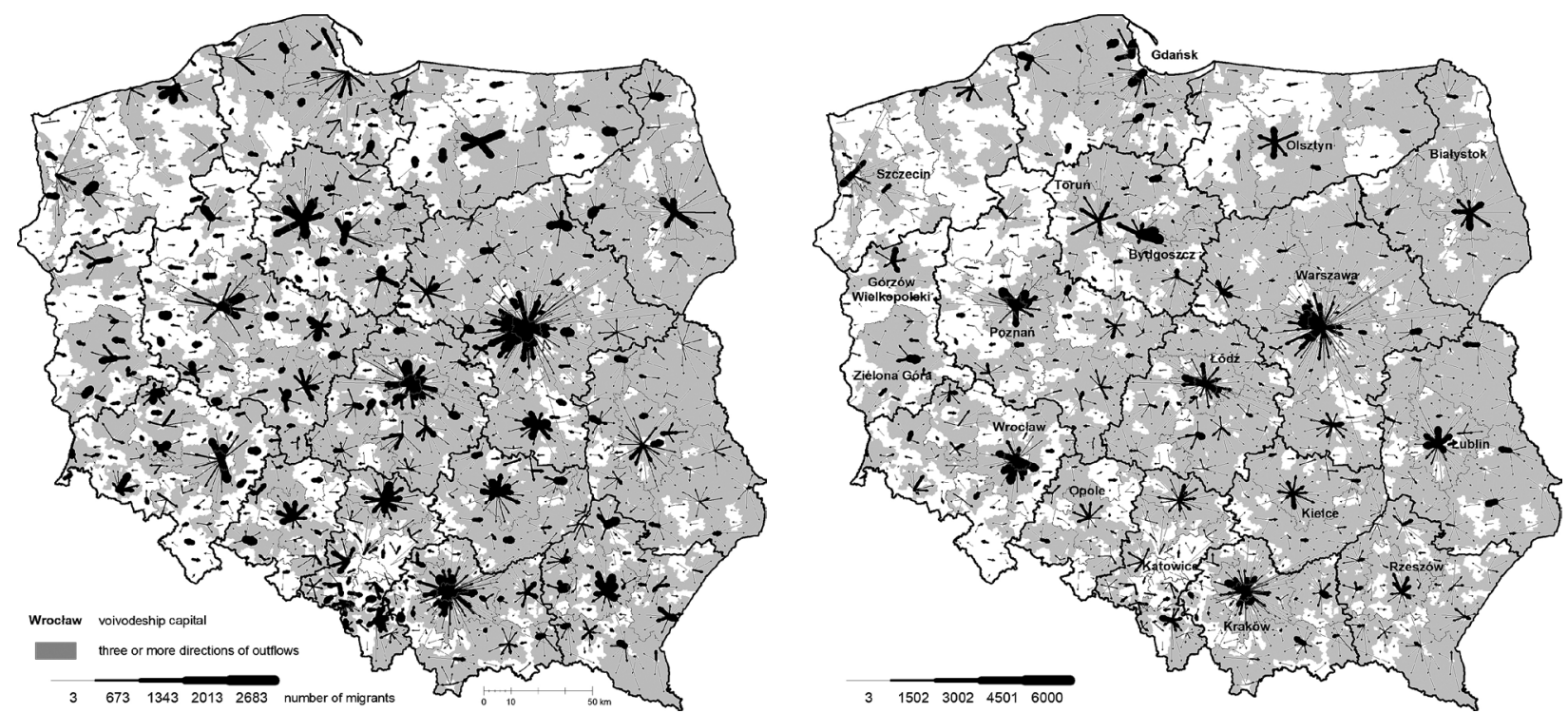

Fig. 3. Areas of migratory attractiveness presented on the scale of migratory movement catchment areas (left) and after trimming off the highest ${ }^{14}$ movement values (right) (linear scaling).

Source: elaborated on the basis of Statistics Poland - Demography database Table $2 \mathrm{~g}$ (http:/ / demografia.stat.gov.pl/ bazademografia/Tables.aspx).

1415 highest values of movements have been trimmed off, over 6,000, made up of totally 118 thousand migrations. 
It should be pointed out that not all the areas of migratory attractiveness, like the catchment areas, are 'fully' developed ${ }^{15}$. In the case of this group of cities, it is hard to detect any regularities in their distribution without further, in-depth analyses. As previously mentioned, in the context of significance of migratory attractiveness, areas measured by the magnitude of movements, apart from the voivodeship capitals of the eastern part, the cities of the western part are privileged. In the case of migratory catchment areas, nearly $31 \%$ of cities are not connected by a maximum flow with any other rural area. Among the group of cities that form an area of migratory influence as much as $63 \%$ of them are underdeveloped. From the remaining $37 \%, 22 \%$ are areas of migratory attractiveness made up of 3-5 communes. Similarly, areas of migratory influence of cities made up of more than 10 communes constitute nearly 6\%. The largest, most complex areas of migratory attractiveness are Warsaw (85 communes) and Cracow (66) (Kurek et al. 2015; Ilnicki, Michalski 2015). The following catchment areas in terms of size (twice as small) are Łódź (40) and Lublin (35).

\section{Rural areas as origins and destinations of migration}

Over the entire study period, nearly 960 thousand people migrated within rural areas. With the exception of two neighbouring years (2006, 2007), nearly 60 thousand people on average migrated annually. The number of migrants 'did not change'. Neither did the share of this type of movements in their total number - it remained stable and was at the average level of $14.9 \%$, fluctuating between 14.2 and $16.1 \%$. As regards the significance of rural - rural movements, over the entire study period, one may be tempted to conclude that following the decline observed between 2002 and 2012 (15.5-14.2\%), it continued to rise. Consequently, it led to reinstating the significance of migration in rural areas in their overall number. Putting aside the statistical dimension of similarities, or differences between its average level and values for particular years, it differed

15 A fully developed migratory catchment area is the one into which migrants inflow from three communes. $\pm 1 \%$ from the average level. In absolute values, it is a little over 4 thousand people.

In each voivodeship, the share of movements in rural areas (rural - rural migration) in the total number of movements for the entire study period in relation to the remaining directions was the lowest. It needs to be stressed, however, that it was the migration direction, which, apart from urban - urban migrations ${ }^{16}$, differentiated voivodeships most. At this point, one needs to draw attention to two facts. The first one is that during the entire study period, no spectacular or even significant changes in the share of movements in rural areas were observed at a voivodeship level. The changes had oscillatory character and fluctuated to a similar extent in plus and in minus from the average value over the entire study period for voivodeships. This resulted in a situation in which the order of voivodeships practically did not change. Naturally, we disregard here the short-lasting changes \pm 1 place. Although differences between consecutive ordered values of the share of movements in 2002-2007 display values from 0.2 to $3.7 \%$, the graph of order seems to show more clearly the arithmetic decline of following values than natural gaps between consecutive voivodeships.

The average share of migration in rural areas in their total number for the duration of the study was $16.1 \%$. Larger-than-average values between 2002 and 2017 were found in six voivodeships. In the descending order, these were: Podkarpackie (26.8\%), Lubelskie $(24.3 \%)$, Świętokrzyskie (23.6\%), Małopolskie (19.9\%), Opolskie (19.5\%), Wielkopolskie (17.4\%), Kujawsko-Pomorskie (16.7\%). This larger-thanaverage share in the structure of migration directions within a given voivodeship is not always reflected in the volume of flow (Fig. 4).

The picture of spatial diversity of the volume of flows within rural areas apart from the previously mentioned Podkarpackie, Małopolskie,

16 Higher span - range - of the share of movements between cities in total results from their increased significance in the case of Śląskie, Mazowieckie, Pomorskie and Dolnośląskie Voivodeships. It is worth mentioning that apart from Śląskie Voivodeship, these voivodeships are characterised by a positive migration balance in the total balance of movements, including Małopolskie and Wielkopolskie Voivodeships. 

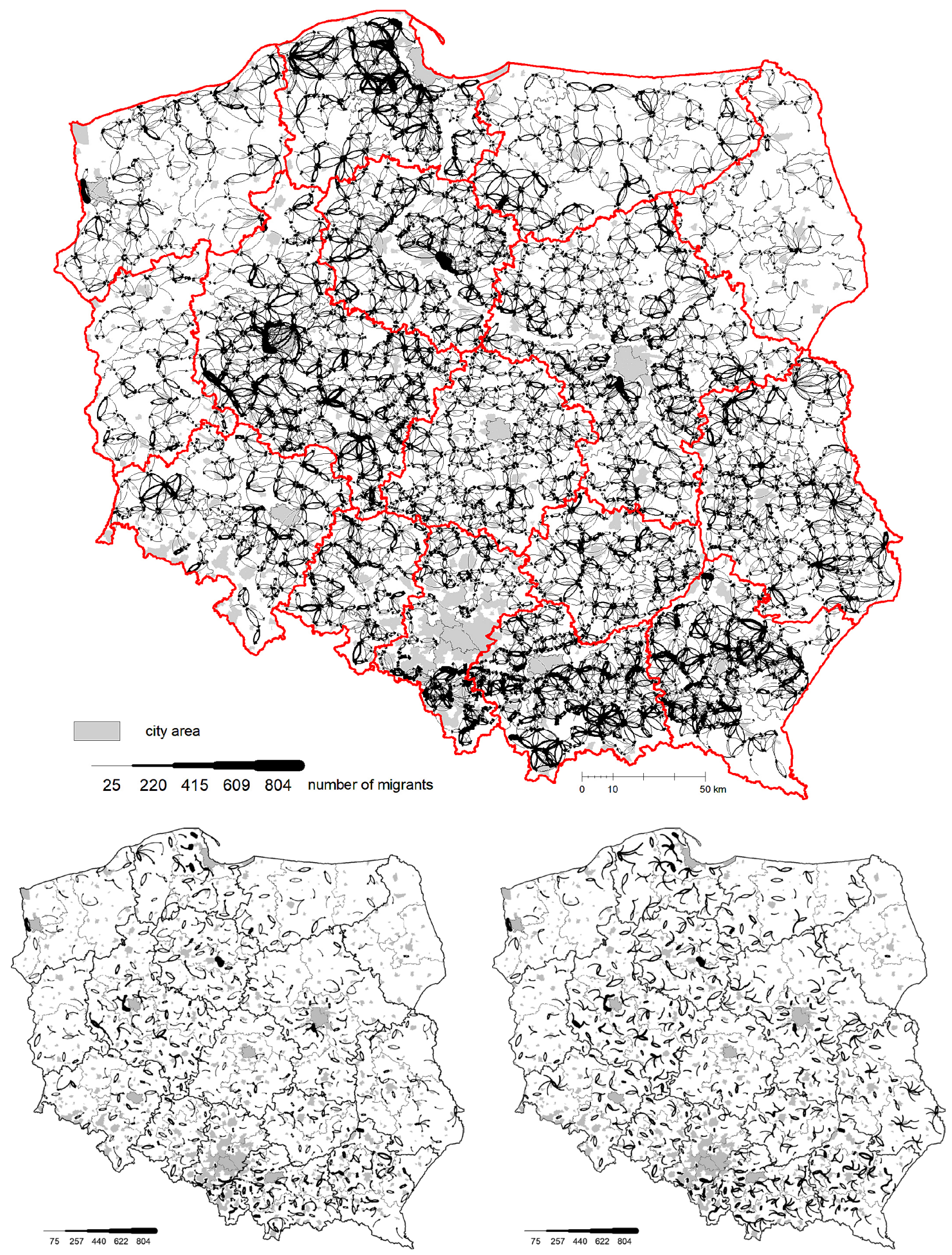

Fig. 4. Rural areas as origins and destinations of permanent internal migrations as well as catchment areas and areas of migratory attractiveness (linear scaling).

Source: elaborated on the basis of Statistics Poland - Demography database Table $2 \mathrm{~g}$ (http:/ / demografia.stat.gov.pl/ bazademografia/Tables.aspx). 
Wielkopolskie and Kujawsko-Pomorskie, one should also include Pomorskie Voivodeship. In this case, there is a relatively large number of movements between particular locations on the one hand, while on the other, these records register not only high, but also the maximum movement values. In the case of the following three voivodeships (Lubelskie, Świętokrzyskie, Opolskie), however, this relative scarcity of high flow values is compensated by the number of rural - rural migrations within a given voivodeship. The background for these movements in rural areas as regards intensity and the share in the migration structure are: Lubuskie, Podlaskie, Warmińsko-Mazurskie, Zachodniopomorskie Voivodeships. One of low and the lowest shares of rural - rural migrations is displayed by Dolnośląskie Voivodeship (9.9\%) and Śląskie Voivodeship (7.5\%). It must be noted, however, that in the case of Dolnoślackie Voivodeship, its central part is clearly visible, and extends from the north-west into the southeast. This is an area traditionally characterised by a highly agricultural economy (Hasiński 2010). In the case of Śląskie Voivodeship, its prominent feature is its urban character resulting from the fact that nearly $53 \%$ of permanent migrations are urban - urban migrations. Moreover, there is a clear tripartite division resulting from the fact that Śląskie Voivodeship was formed by combining former Częstochowskie, Katowickie and Bielsko-Bialskie Voivodeships. Although this is not reflected in the share of migrations in rural areas, their intensity is relatively high, and is manifested in their number and volume. It is worth noting that the Vistula River forms a clear boundary of permanent migration within the rural areas. However, in the context of the previous rural - urban - rural movements, it is important to note that rural - rural migrations are short-distance migrations, between neighbouring communes and have the character of linkages, return flows.

When identifying the catchment areas and areas of migratory attractiveness, their picture is a derivative of permanent migration as a whole. In the case of both areas, we can hardly talk about clearly established 'migratory regions'. These are usually return connections, feedbacks, concentrating up to five directions. The return element is to a greater extent observed in the areas of migratory attractiveness. Migratory catchment areas, on the other hand, display a nodal character to a greater extent. Fundamentally, catchment areas and areas of migratory attractiveness very rarely have a classic radial character. The lack of an evident tendency to form clear catchment areas may not so much result from a national perspective, but rather from variability of flows between voivodeships and the significance of movements within rural areas. Therefore, it seems that by narrowing studies to one or two voivodeships, regional specificity of migratory movements might contribute to the identification of migration regions.

\section{Summary and final conclusions}

In the day and age of an information economy, in which, on the one hand, there is only 'here and now', and on the other, changes are so dynamic, it is hard to identify and assess them in real time without keeping a distance. There are, however, some things that not so much undergo changes, but rather display a significant degree of inertia or 'stability'. These are spatial structures, spatial diversity of both social as well as economic phenomena. In other words, the intensity, the scale of the phenomenon changes, but its spatial structure, at least at the general level, remains unchanged. This does not mean that spatial structures do not undergo changes. This is, however, a long-lasting process, as it is the matter, and not an 'idea', which appears and disappears in virtual reality overnight.

Permanent internal migrations appear to be a phenomenon characterised by a well-established spatial structure. Obviously, this statement is certainly true for the timeframe covering the study period. Although it is hard to foresee the future, it is highly likely that most of the above observations and regularities are rooted in the past. We can safely presume that in the 1990s in Poland, there occurred a shift in the dominant migration patterns - the rural - urban direction was inverted and is now urban - rural. Regardless of the determinants and reasons that led to this situation, the statistics that are the basis for this study allow not only for confirming common opinions and beliefs concerning the ongoing processes of suburbanisation and development of suburban 
zones as well as the difference in the scale of migratory phenomena between cities and rural areas, but also for formulating the author's own conclusions. It is important to note that the present study is not a case study the results of which are transposed onto the entire population or space.

Above all, it is important to stress high convergence, if not overlapping, of the spatial scopes of migratory catchment areas and areas of migratory attractiveness of cities. It needs to be noted, however, that migratory catchment areas in terms of migration magnitude, have greater reach compared to that of migratory attractive areas. Permanent migration from cities into rural areas takes place, in the majority of cases, into the suburban zones. These migrations are largely the result of, but also probably the reason for, the increased volume of housing construction in close vicinity of cities. Due to the fact that the subjects of permanent migration into suburban zones are young people just before, or just after entering (in)formal relationships, this value seems to be a good variable, useful in the identification of urban functional areas at various levels of urban hierarchy. Permanent internal migrations within rural areas are less significant among all the directions of migration. They share a characteristic feature, that is, they usually take place between locations that aren't remote, between neighbouring units. At the same time, the absolute value of movements, as well as the largest streams, are observed in the voivodeships characterised by the above-average share of movements, where rural areas are at the same time the origin and destination of migration. In their catchment areas, as well as areas of migration attractiveness, they are less developed compared to those where rural areas are the origin and destination of migrations to and from cities. It needs to be mentioned that in majority of cases, these areas have feedback character. Only in a few cases, they have the structure and layout of a nodal region.

In the case of migratory laws of Ravenstein, there is a clear reference to at least four laws:

- the correlation between the migration volume and the distance;

- the fact that a stream generates a counterstream;

- difference in migration tendencies between cities and rural areas;
- the dominant role of economic factor as stimulating migration - in this case understood as 'unattractive climate, unsuitable social surrounding'.

In relation to the model based on the concepts developed by Lee, we can talk about the correspondence to the following hypotheses:

- the migration volume changes together with diversity of the population;

- the migration volume is connected with the difficulty of overcoming indirect obstacles;

- if there are no significant disincentives imposed, both the volume as well as intensification of migration tend to increase with time;

- each bigger migratory stream generates a counterstream;

- the volume of stream changes together with economic conditions, increasing in time of prosperity, and decreasing in crisis;

- the characteristic of migrants is a blend of characteristics of the population in their place of origin and destination.

It is important to note that when attempting to analyse migration (but not only) with the use of absolute values, it is necessary to stratify the analysis. Analysis stratification consists in comparison of similar units - capitals of voivodeships, urban poviats, cities from a similar size group and so on. On the one hand, there is analysis stratification, but on the other, there are regionalisms, specific features found in particular regions or their groups, which have their contemporary as well as historical determinants. While this article deals with migrations and revolves around rural areas on the national scale, it seems necessary to deepen and expand the analysis for selected parts of the country. Such activities should not, however, copy the research approach applied on the national scale, but rather aim at the actual delimitation, defining the boundaries of migratory catchment areas and areas of migratory attractiveness. At the same time, they should be confronted against the scopes of the following: suburban zones, urban functional areas, zones undergoing heavy urbanisation - suburbanisation. This would result in a valid verification of the actual scope of (rural) areas, which are in constant feedback with cities. Another reason that also validates analysing permanent migration within particular voivodeships is the fact that most migrations among this group take place 
within one voivodeship. The validity of applying the approach using absolute values of flows and the highest flow are hardly questionable. However, it would be advisable to investigate the spatial structure of migration for each year separately as well as apply a relative approach in order to determine movement volume so that it might be used in the identification of catchment areas of migratory attractiveness.

\section{References}

Arango J., 2000, Explaining migration a critical view. International Social Science Journal 165, Blackwell Publishers / UNESCO: 283-296.

Bałach-Frankiewicz J., Ciok S., Ilnicki D., 2016. Struktura funkcjonalno-przestrzenna lokalnego zespołu osadniczo-produkcyjnego Jelcza-Laskowic (Functional-spatial structure of the local settlement-production team Jelcz-Laskowice). Rozprawy Naukowe Instytutu Geografii i Rozwoju Regionalnego 39.

Böheim R., Taylor M.P., 2007. From the dark end of the street to the bright side of the road? The wage returns to migration in Britain. Labour Economics 1: 99-117.

Bramley G., Champion T., Fisher T., 2006. Exploring the household impacts of migration in Britain using panel survey data. Regional Studies 40(8): 907-926.

Brettell C.B, Hollifield J.F. 2008. Migration theory. Talking across disciplines. In: Brettell C.B., Hollifield J.F. (eds), Migration theory. Talking across disciplines. Routledge, New York: 1-30.

Casteles S., Miller M.J., 2011. Migracje we wspótczesnym świecie (Migrations in today's world), Wydawnictwo Naukowe PWN, Warszawa.

Chapman J., Bernstein J., 2003, Immigration and poverty: How are they linked? Monthly Labour Review 4: 10-29.

Ciok S., Ilnicki D., 2018. Przestrzenne i czasowe zróżnicowanie budownictwa mieszkaniowego w Polsce (Spatial and time differences in housing construction in Poland). In: Churski P. (ed.), Teoretyczne i aplikacyjne wyzwania współczesnej geografii społeczno-ekonomicznej (Theoretical and application challenges of contemporary socio-economic geography), Studia KPZK PAN 183: 333-344.

De Haas H., 2008. Migration and development. A theoretical perspective. Working papers no 9, University of Oxford. International Migration Institute.

Dennett A., Stillwell J., 2008, Internal migration in Great Britain - a district level analysis using 2001 Census data, working paper 01/08, School of Geography, University of Leeds, LS2 9JT.

Domańska L., 2006. Migracja zarobkowa Polaków do krajów Unii Europejskiej (Economic migration of Poles to the EU states). Zeszyty Naukowe Politechniki Rzeszowskiej. Zarzadzanie i Marketing 6: 67-72.

Douglas S.M., Arango J., Hugo G., Kouaouci A., Pellegrino A., Taylor J.E., 2006. Theories of international migration: A review and appraisal. In: Messina A.M., Lahav G. (eds), The migration reader. Exploring politics and policies. Lynne Rienner Publishers, Boulnder, London: 34-62.
Faggian A., McCann P., Sheppard S., 2007. Some evidence that women are more mobile than men: Gender differences in UK graduate migration behaviour. Journal of Regional Science 47(3): 517-539.

Gawryszewski A., 1974. Związki przestrzenne między migracjami stałymi i dojazdami do pracy oraz czynniki przemieszczeń ludności (Spatial relations between permanent migrations and commuting as well as factors of population movements). Prace Geograficzne IG PAN 109.

Gawryszewski A., 1989. Przestrzenna ruchliwość ludności Polski 1952-1985 (Spatial mobility of Poland's population 1952-1985). Ossolineum, Wrocław.

Glick Schiller N., 2011. A global perspective on migration and development. In: Faist T., Fauser M., Kivisto P. (eds), The migration-development nexus. A transnational perspective. Palgrave Macmillan, Hampshire: 29-56.

Gober-Meyers P., 1978. Migration analysis: The role of geographical scale. The Annals of Regional Science 12(3): 52-61.

Gregory D., Johnston R., Pratt G., Watts M.J., Whatmore S. (eds), 2009. The Dictionary of Human Geography. 5th Edition. John Wiley \& Sons, Ltd. - Blackwell Publication.

Greta M., Lewandowski K., 2007. Ekonomiczne skutki migracji: analiza na przykładzie krajów Wspólnoty Europejskiej (Economic effects of migration: Analysis on the example of the EC countries). Gospodarka w Praktyce $i$ Teorii 1: 45-54.

Halik T., 2006. Migrancka społeczność Wietnamczyków w Polsce w świetle polityki państwa i ocen społecznych (Migrant community of the Vietnamese in Poland in the light of the state's policy and social evaluation). Seria Badania Interdyscyplinarne 5, Adam Mickiewicz University Press, Poznań.

Harańczyk A., 2015. Procesy suburbanizacji w Krakowskim Obszarze Funkcjonalnym (Suburbanisation processes in the Cracow Functional Area). Studia Miejskie 18, Katedra Geografii Ekonomicznej i Gospodarki Przestrzennej, Wydział Ekonomiczny, Uniwersytet Opolski: 85-102.

Hardwick S.W., 2008. Place, space, and pattern. Geographical theories in international migration In: Brettell C.B., Hollifield J.F. (eds), Migration theory. Talking across disciplines, Routledge, New York: 161-182.

Hasiński W., 2010. Integracja pozioma gospodarstw rolnych w Polsce ze szczególnym uwzględnieniem województwa dolnośląskiego (Horizontal integration of farms in Poland with particular emphasis on Dolnośląskie Voivodeship). In: Ciok S., Migoń P. (ed.), Przeksztatcenia struktur regionalnych. Aspekty społeczne, ekonomiczne i przyrodnicze (Transformations of regional structures. Social, economic and environmental aspsects), Instytut Geografii i Rozwoju Regionalnego, Uniwersytet Wrocławski: 349-360.

Heffner K., Gibas P., 2015. Obszary funkcjonalne i ich związki z zasięgiem oddziaływania z ośrodków subregionalnych (na przykładzie województwa opolskiego) (Functional areas and their relations with the impact range with subregional centres [illustrated by Opolskie Voivodeship]). Studia Miejskie 18, Katedra Geografii Ekonomicznej i Gospodarki Przestrzennej, Wydział Ekonomiczny, Uniwersytet Opolski: 9-24.

Heffner K., Rauzińki R., 2003. Region migracyjny (wybrane aspekty demograficzne, społeczne i gospodarcze na przykładzie Śląska Opolskiego) (A migration region [selected demographic, social and economic aspects on the example of Śląskie Voivodeship]). Studia i Monografie 152, Wydawnictwo Politechniki Opolskiej: 141-153. 
Herma J., 1962. Dojazdy do pracy w województwie krakowskim (Commuting in Krakowskie Voivodeship). Rocznik naukowo-dydaktyczny WSP w Krakowie, Prace Geograficzne 10: 120-141.

Hollifield J.F., 2008. The politics of international migration. How can we "bring the state back in". In: Brettell C.B., Hollifield J.F. (eds), Migration theory. Talking across disciplines. Routledge, New York: 183-238.

Huk J., 2004. Migracje ludności na Dolnym Śląsku w latach 1989-1998: kierunki i efektywność (Migrations of the population in Lower Silesia in the years 1989-1998: Directions and efficiency). Czasopismo Geograficzne 75(1/2): 33-64.

Iglicka K., 2006. Dylematy europejskiej polityki migracyjnej (Dilemmas of European migration policy). Nowa Europa 2: 148-164.

Ilnicki D., Michalski P., 2015. Powiązania funkcjonalnoprzestrzenne $\mathrm{w}$ świetle dojazdów do pracy (Functional and spatial relations in the light of commuting to work). Studia Miejskie 18, Katedra Geografii Ekonomicznej i Gospodarki Przestrzennej, Wydział Ekonomiczny, Uniwersytet Opolski: 55-70.

Jelonek A., 2005. Rozwój urbanizacji i jej etapy w Polsce w latach 1946-2002 (Urbanisation development and its stages in Poland in 1946-2002). In: Jażdżewska I. (ed.), Wspótczesne procesy urbanizacji i ich skutki (Today's urbanisation processes and their effects), XVIII Konwersatorium wiedzy o mieście, Wydawnictwo Uniwersytetu Łódzkiego: $37-46$.

Kajdanek K., 2009. Rozwój strefy podmiejskiej Wrocławia w perspektywie socjologii (Development of the Wrocław suburban zone from the sociological perspecitve). In: Jażdżewska J. (ed.), Strefa podmiejska i mate miasta w okresie transformacji (Suburban zone and small towns in the transformation period), XXII Konwersatorium wiedzy o mieście, Wydawnictwo Uniwersytetu Łódzkiego: 129144.

Kosiński L., 1968. Migracje ludności w Polsce w latach 19501960 (Migration of the population in Poland in 19501960). Prace Geograficzne 72, Instytut Geografii PAN, PWN.

Kurek S., Wójtowicz M., Gałka J., 2015. Powiązania funkcjonalno-przestrzenne $\mathrm{w}$ krakowskim obszarze metropolitalnym w świetle dojazdów do pracy (Functional and spatial relations in the Kraków metropolitan area in the light of commuting to work). Studia Miejskie 18, Katedra Geografii Ekonomicznej i Gospodarki Przestrzennej, Wydział Ekonomiczny, Uniwersytet Opolski: 55-70.

Lee E.S., 1966. A theory of migration. Demography 3(1): 47-57 (trans. 1972. Teoria migracji). In: Modele Migracji. Przeglad Zagranicznej Literatury Geograficznej 3/4 IGiPZ PAN, Warszawa: 9-28.

Łodyga B., 2011. Demograficzne skutki suburbanizacji w aglomeracji poznańskiej (Demographic effects of suburbanisation in the Poznań agglomeration). In: Słodczyk J. (ed.), Studia Miejskie 3, Procesy suburbanizacji w wybranych miastach Polski. Katedra Geografii Ekonomicznej i Gospodarki Przestrzennej, Wydział Ekonomiczny, Uniwersytet Opolski: 113-138.

Mantay D., 2009. Wybrane społeczne aspekty żywiołowej suburbanizacji w południowo-zachodniej strefie podmiejskiej Warszawy (Selected social aspects of unrestrained suburbanisation in the south-western suburban zone of Warsaw). In: Maik W. (ed.), Aglomeracje miejskie w Polsce na przełomie XX i XXI wieku. Problemy rozwoju, przekształceń strukturalnych i funkcjonowania (Urban agglomerations in Poland at the turn of the 21st century. Problems of development, structural transformations and functioning), Instytut Geografii i Gospodarki Przestrzennej, Wyższa Szkoła Gospodarki w Bydgoszczy, Wydawnictwo Uczelniane WSG: 363-378.

Massey D.S., Arango J., Hugo G., Kouaouci A., Pellegrino A., Taylor J.E., 1998. Worlds in motion. Understending international migration at the end of the millenium. Oxford, Clarendon, University Press.

Massey D., 1990. Social structure, household strategies, and the cumulative causation of migration. Population Index $56(1): 3-26$.

Molloy R., Smith C.,L., Wozniak A., 2011. Internal migration in the United States. Journal of Economic Perspectives 25(3): 173-196.

Morrison A.R., Schiff M., Sjöblom M. (eds), 2008. The international migration of women. World Bank, Palgrave Macmillan, Washington.

Nita B., 2005. Przepływy siły roboczej między Polską i innymi krajami ze szczególnym uwzględnieniem krajów Unii Europejskiej (Flows of labour force between Poland and other countries with particular emphasis on the EU states). Politechnika Radomska im. Kazimierza Pułaskiego, Prace Naukowe Ekonomika 2: 71-89.

Pasamonik A., 2008. Imigrantki w społeczeństwach Zachodu: emancypacja i integracja (Female immigrants in Western society: Emancipation and integration). Kultura i Społeczeństwo 52(2): 57-78.

Przygalińska M., 2006. Przeobrażenia struktury społeczno-ekonomicznej ludności migrującej w Polsce w latach 1975-2001 (Transformations of socio-economic structure of the migrating population in Poland in 1975-2001). Prace statystyczne i demograficzne, Akademia Ekonomiczna w Poznaniu, Wydawnictwo Akademii Ekonomicznej w Poznaniu: 81-104.

Radwańska M., 2009. Ciążenie ludności do ośrodka rdzeniowego aglomeracji, na przykładzie Torunia (Gravitation of people to the core centre of an agglomeration on the example of Toruń). In: Maik W. (ed.), Aglomeracje miejskie $w$ Polsce na przetomie XX i XXI wieku, Problemy rozwoju, przeksztatceń strukturalnych i funkcjonowania (Urban agglomerations in Poland at the turn of the 21st century, Problems of development, structural transformations and functioning), Instytut Geografii i Gospodarki Przestrzennej, Wyższa Szkoła Gospodarki w Bydgoszczy, Wydawnictwo Uczelniane WSG: 333-346.

Rakowska J., 2014. Codzienne dojazdy do pracy jako ekonomiczne kryterium rządowych klasyfikacji i delimitacji obszarów (na przykładzie USA i Kanady) (Daily commuting as an economic criterion for government classification and delimitation of areas [on the example of the USA and Canada]). Studia Regionalne $i$ Lokalne 3(57): 46-59.

Ravenstein E.G., 1885. The laws of migration. Journal of the Statistical Society of London 48(2): 167-235.

Ravenstein E.G., 1889. The laws of migration. Journal of the Royal Statistical Society 52(2): 241-305.

Rettinger R., Wójtowicz M., 2009. Rozwój budownictwa mieszkaniowego w obrębie Krakowskiego obszaru metropolitalnego (KOM) ze szczególnym uwzględnieniem gminy Zabierzów (Development of housing construction within the Cracow metropolitan area with particular emphasis on the commune of Zabierzów). In: Jażdżewska I. (ed.), Strefa podmiejska i mate miasta w okresie transformacji 
(Suburban zone and small towns in the transformation period), XXII Konwersatorium wiedzy o mieście, Wydawnictwo Uniwersytetu Łódzkiego: 129-144.

Rosner A., 2014. Migracje wewnętrzne i ich związek z przestrzennym zróżnicowaniem rozwoju społeczno-gospodarczego wsi (Internal migrations and their relations with spatial differences in rural socio-economic development). Wieś i rolnictwo 1(162): 63-79.

Samoraj B., 2008. Polska w Schengen a nielegalna migracja. Monitor Unii Europejskiej 1: 55-64.

Schuck P.H., 2008. Law and the study of migration. In: Brettell C.B., Hollifield J.F. (eds), Migration theory. Talking across disciplines. Routledge, New York: 239-258.

Slany K. (ed.), 2008. Migracje kobiet: perspektywa wielowymiarowa (Migration of women: A multidimensional perspective). Wydawnictwo Uniwersytetu Jagiellońskiego, Kraków.

Stillwell J., Hussain S., 2010. Exploring the ethnic dimension of internal migration in Great Britain using migration effectiveness and spatial connectivity. Journal of Ethnic and Migration Studies 36(9): 1381-1403.

Stouffer S.A., 1940. Intervening opportunities. A theory relating mobility and distance. American Sociological Review 5: 845-867.
Teitelbaum M.S., 2008. Demographic analyses of international migration. In: Brettell C.B., Hollifield J.F. (eds), Migration theory. Talking across disciplines. Routledge, New York: 51-62.

Tracz D., 2006. Migracja zarobkowa jako element przemian rynku pracy w aspekcie integracji europejskiej (Economic migration as an element of changes on the labour market in the aspect of European integration). Zeszyty $\mathrm{Na}$ ukowe Politechniki Rzeszowskiej. Zarzadzanie i Marketing 6: 347-354.

Wach K., 2007. Europejska swoboda przepływu pracowników (European freedom in the movement of workers). Studia Europejskie 3(43) Warszawa: 183-195.

Weinar A., 2006. Europeizacja polskiej polityki wobec cudzoziemców 1990-2003 (Europeanisation of the Polish policy towards foreigners 1990-2003). Centrum Stosunków Międzynarodowych, Wydawnictwo Scholar, Warszawa.

Więcław-Michniewska J., 2006. Krakowskie suburbia $i$ ich społeczność (Cracow suburbia and its community). Instytut Geografii i Gospodarki Przestrzennej, Uniwersytet Jagielloński.

Wójcik Ł., 2007. Doświadczenia Hiszpanii w polityce imigracyjnej: konieczne wspólne działania UE (Experience of Spain in immigration policy: A need for the EU joint action). Monitor Unii Europejskiej 6: 88-92. 